\title{
INTERIM FINANCING THROUGH USE OF THE TURNOVER POWER IN RAILROAD REORGANIZATIONS
}

A MAJOR line in the rail transportation system is presently in reorganization, ${ }^{1}$ and other railroads face similar financial difficulties. ${ }^{2}$ Greater competition with alternative modes of transportation and higher taxes and wages have substantially reduced the net profits of the railroads, impairing their ability to satisfy the fixed interest and matured obligations of outstanding debt. Section 77,3 the railroad reorganization provision of the Bankruptcy Act, ${ }^{4}$ will thus be increasingly called upon to alleviate their economic plight. Reorganization attempts to solve the problems caused by the combination of unprofitable operations and high fixed charges: profits are increased by abandonment of loss routes, ${ }^{5}$ interest obligations are reduced by decreasing the total amount of outstanding debt, ${ }^{6}$ and secured creditors are prevented from interfering with the property of the insolvent company by removing or modifying liens and mortgages. ${ }^{7}$

Unlike ordinary bankruptcy proceedings, where the insolvent corporation is liquidated to satisfy the claims of unsecured creditors, a section 77 reorganization contemplates the rehabilitation of the debtor corporation. ${ }^{8}$ Reorganiza-

1. See, e.g., N.Y. Times, Jan. 17, 1962, p. 1, col. 2, for reference to the New York, New Haven \& Hartford Railroad.

2. See, e.g., N.Y. Times, March 1, 1962, p. 1, col. 8; N.Y. Times, March 4, 1962, § 3 (Financial), p. 1, col. 8.

3. 49 Stat. $911-26$ (1935), 11 U.S.C. $\$ 205$ (1958). The 1935 version of the act represents an extensive amendment of an earlier version passed hurriedly in 1933, 47 Stat. 1474 (1933), 11 U.S.C. \& 205 (1958). See note 37 infra and accompanying text.

4. Section 77 applies only to railroads in interstate commerce. Section $77(\mathrm{~m}), 49$ Stat. 922 (1935), 11 U.S.C. \$ 205 (m) (1958).

5. Section 77(o), 49 Stat. 923 (1935), 11 U.S.C. \& 205(o) (1958); In re Denver \& Rio Grande W. R. Co., 32 F. Supp. 244 (D. Col. 1940) ; 5 ColLIER, BANKRUPTCY II 77.25, at 550 (14th ed. 1954) [hereinafter cited as CoLlier with publication date of volume].

6. Section 77(b), 49 Stat. 911 (1935), 11 U.S.C. § 205(b) (1958).

"The grant of power to establish ... uniform Laws on the subject of Bankruptcies," U.S. CoNsr. art. $1, \S 8$, cl. 4, was necessarily a grant of power the exercise of which would impair the obligations of contracts. While Congress may not act directly to negate private contracts, it has the power to enact legislation on the subject of bankruptcies, pursuant to which section 77 was enacted, which may operate collaterally or incidentally to that end. Continental Ill. Nat'l Bank \& Trust Co. v. Chicago, R. I. \& Pac. Ry., 294 U.S. 648 (1935).

7. Section 77(a), 49 Stat. 911 (1935), 11 U.S.C. § 205(a) (1958); Continental III. Nat'l Bank \& Trust Co. v. Chicago, R. I. \& Pac. Ry., 294 U.S. 648 (1935). Accord, In re Central of Georgia Ry., 42 F. Supp. 940 (S.D. Ga., 1942) ; Van Schaick v. McCarthy, 116 F.2d 987 (10th Cir. 1941).

8. Section 77(b), 49 Stat. 911 (1935), 11 U.S.C. $\S 205$ (b) (1958). See also In re Huntington \& Broad Top Mt. R.R. \& Coal Co., 213 F.2d 411, 416 (3d Cir. 1954).

At the very least, maintenance of the status quo is essential during the development of the reorganization plan, the object of which is to rehabilitate and overhaul the debtor's 
tion is intended, in fact, to avoid the economic waste inherent in the liquidation of any corporation and especially inherent in the dismantling of a railroad and the selling of its property piecemeal. ${ }^{9}$ Although the rights of secured creditors may not be impaired under ordinary bankruptcy proceedings, ${ }^{10}$ section 77 authorizes a court to modify the rights of all creditors, whether secured or unsecured ;11 thus, the court may alter liens, indentures, or other similar interests, cure or waive defaults, extend the maturity dates of outstanding securities, and reduce the principal or rate of interest of secured bonds. ${ }^{12}$ Congress believed that the power to affect the rights of secured creditors ${ }^{13}$ was essential to the effective reorganization of railroads, ${ }^{14}$ since most railroad property is usually subject to liens established by virtue of debt indenture bonds. ${ }^{15}$ The justification for the authority to deal with secured debts is that the public interest is better served by continued operation of the insolvent railroad ${ }^{16}$ and that all creditors will ultimately recover a greater proportion of their claims by the rehabilitation of the debtor's business. ${ }^{17}$

Moreover, reorganization as a substitute for liquidation is designed to preserve the proportionate values of all investments, including senior secured debts. ${ }^{18}$ Thus, the requirement of section 77 that the plan be "fair and equitable"10 has been held to require that security holders receive in the order of

financial structure. Van Schaick v. McCarthy, 116 F.2d 987 (10th Cir. 1941). See also Central Hanover Bank \& Trust Co. v. Philadelphia \& Reading Coal \& Iron Co., 99 F.2d 642, 645 (3d Cir. 1938); In re Moulding-Brownell Corp., 101 F.2d 664, 665 (7th Cir. 1939).

9. Cf., Gerdes, Corporate Reorganization Under Section 77B of the Bankruftcy Act 3 (1936).

10. In re Prudence-Bonds Corp., 75 F.2d 262, 263 (2d Cir. 1935); Taubel Co. v. Fox, 264 U.S. 426, 434 (1924).

11. Section 77(b), 49 Stat. 911 (1935), 11 U.S.C. § 205(b) (1958). See also Van Schaick v. McCarthy, 116 F.2d 987, 992-93 (10th Cir. 1941) ; In re Prudence-Bonds Corp., 75 F.2d 262, 263 (2d Cir. 1935).

12. Section 77(b) (5), 49 Stat. 911 (1935), 11 U.S.C. $\$ 205$ (b) (5) (1958) ; 5 Cortrer \77.13, at 511 (1954).

13. 1 GERDES, op. cit. supra note $9, \S 28$, at 99 .

14. Section 77 , as opposed to ordinary bankruptcy, deals largely with secured debt. 5 Collier If 77.21, at 539 n.9 (1954). See also 1 GERDES, op. cit. supra note 9 , § 28, at 99 .

The consent of secured creditors was needed in equity receivership. Ibid.

15. Oleck, Creditors' Rights and Remedies 89 (1949); Clay, The Case for a Special Railroad Reorganization Court, 7 LAW \& ConteMP. ProB. 450 (1940).

This system of financing creates a hierarchy of priorities among creditors, which becomes increasingly complex as separate railroads merge. Barriger, The Development of Railway Corporate Structures, 7 LAw \& Contearp. Prob. 367 (1940).

16. Ecker v. Western Pac. R.R., 318 U.S. 448, 469 (1943) ; Continental Ill. Nat'l Bank \& Trust Co. v. Chicago, R. I. \& Pac. Ry., 294 U.S. 648 (1935). See also 5 CollIER, If 77.02, at 468 (1954).

17. Blum, The Law and Language of Corporate Reorganization, 17 U. CHI. L. REv. 565, 586 (1950). See RFC v. Kaplan, 185 F.2d 791, 793-94 (1st Cir. 1950).

18. In re Third Ave. Transit Corp., 198 F.2d 703 (2d Cir. 1952); In re Day, Meyer, Murray \& Young, Inc., 93 F.2d 657 (2d Cir. 1938). See also Note, 64 Y YLE L.J. 412, 420 (1955).

19. Section 77 (e) (1), 49 Stat. 911 (1935), 11 U.S.C. § 205 (e) (1) (1958). 
their priority an equivalent interest in new securities. ${ }^{20}$ However, although section 77 thus affords some protection to secured creditors, ${ }^{21}$ it also commands that the reorganization plan be feasible. ${ }^{22}$ Feasibility, besides requiring abandonment of loss routes and managerial changes, demands the development of an economically sound and workable capital structure in order to create and maintain solvency. But a financially feasible plan, by reducing the amount of debt obligation and interest charges, necessarily conflicts with the objective of protecting the interests of secured creditors. ${ }^{23}$

Although the ICC formulates the ultimate plan of reorganization, ${ }^{24}$ the federal district courts supervise and control the continued existence of the debtor corporation during the time-consuming process of reorganization. ${ }^{25}$ Throughout this period the courts must frequently decide whether to permit the reorganization trustee to raise and expend funds. When the expenditures are necessary for maintenance of service, the courts generally permit some impairment of the rights of secured creditors, ${ }^{26}$ in order to prevent the loss of the road's competitive position and the deterioration of its physical plant. $^{27}$

A problem arises when the reorganization trustee seeks to expend funds in the possession of the secured creditors. Deteriorated trains, tracks, or non-

20. The position of junior claimants is not to be improved at the expense of senior claimants. Cf., Case v. Los Angeles Lumber Co., 308 U.S. 106 (1939) ; Ecker v. Western Pac. R.R., 318 U.S. 448 (1943).

21. Finletter, The Law of Bankruptcy Reorganization 430 (1939).

But the priority of public over private rights is recognized. In re Missouri Pac. R.R., 129 F. Supp. 392 (E.D. Mo. 1955), aff'd, 225 F.2d 761 (8th Cir. 1955), cert. denied, 350 U.S. 959 (1956); Swaine, A Decade of Railroad Reorganization Under Section 77 of the Federal Bankruptcy Act, 56 HARv. L. Rev. 1193, 1207-08 (1943).

22. Sections 77(b) (4) \& (d), 49 Stat. 913, 917 (1935), 11 U.S.C. $\S \S 205$ (b) (4) \& (d) (1958).

23. Calkins, Feasibility in Plans of Corporate Reorganization Under Chapter X, 61 Harv. L. Rev. 763 (1948) ; Comment, 51 Yale L.J. 85, 88-113 (1941); Comment, 4 Stan. L. REv. 125 (1951).

24. Section 77(d), 49 Stat. 911 (1935), 11 U.S.C. § 205(d) (1958). See also Ecker v. Western Pac. R.R., 318 U.S. 448, 467-68 (1943). The formulation of the policy and details of the reorganization plan are assigned to the expertise of the ICC. Rodgers \& Groom, Reorganization of Railway Corporations Under Section 77 of the Bankruptcy Act, 33 Colur. L. Rev. 571 (1933).

25. See, e.g., In re Prudence-Bonds Corp., 77 F.2d 328, 330 (2d Cir. 1935).

26. As the court said in In re Wisconsin Cent. Ry., 64 F. Supp. 251, 252 (D. Minn. 1946) :

Trustees of the debtor have the right to use the income to operate the debtor railroad and ... [secured creditor] claims are subsequent to that right.

See also Harding v. Stichman, 240 F.2d 289 (2d Cir. 1957) ; In re St. Louis Southwestern Ry., 17 F. Supp. 68 (E.D. Mo. 1936), aff'd sub non. Bankers Trust Co. v. Henwood, 88 F.2d 163 (8th Cir. 1937).

27. Van Schaick v. McCarthy, 116 F.2d 987, 993 (10th Cir. 1941) ; In re MouldingBrownell Corp., 101 F.2d 664, 665 (7th Cir. 1939); Central Hanover Bank \& Trust Co. v. Philadelphia \& Reading Coal \& Iron Co., 99 F.2d 642, 645 (3d Cir. 1938). 
operational property, such as excess land, which represents security of bondholders under a trust indenture, are often sold by the railroad and the proceeds turned over to the indenture trustee to hold as collateral for the benefit of secured creditors. ${ }^{28}$ Most indenture contracts allow the railroad management to draw upon these funds for necessary improvements so long as the company is not in default. The creditors are protected, however, by a lien which attaches to the property purchased with such funds. But if the company is in default, as it frequently would be when in reorganization, ${ }^{29}$ the management may not use these funds for needed repairs or additions. However, the reorganization trustee, who manages the railroad while the plan is being formulated, needs all available funds to sustain service during the process of reorganization. It is not clear whether the courts have the authority to compel the trustee for the secured creditors to turn over funds in his possession to the reorganization trustee, ${ }^{30}$ and, if they do, under what circumstances this power should be exercised.

Section 77 on its face does not grant the district courts power to order the transfer of such funds, although section $257^{31}$ of Chapter $\mathrm{X}$ of the Bankruptcy Act, the reorganization provision which applies to all corporations other than interstate railroads, ${ }^{32}$ expressly grants the courts this power. It states:

The trustee or debtor in possession shall also have the right to immediate possession of all property of the debtor in the possession of a trustee under a trust deed or a mortgagee under a mortgage. ${ }^{33}$

Since section 257 of Chapter $\mathrm{X}$ provides for the turnover power, and section 77 of the same act contains a series of affirmative powers without including this one, it is arguable that Congress did not intend the district courts to authorize transfer of collateral security to the reorganization trustee in section 77 reorganizations. ${ }^{34}$ Section $101^{35}$ states, moreover, that the provisions of Chapter X "shall apply exclusively to proceedings under this chapter." But

28. See, e.g., In re Third Ave. Transit Corp., 198 F.2d 703 (2d Cir. 1952).

29. Reorganization may be instituted when the debtor is insolvent or unable to pay its debts as they mature. Section 77 (a), 49 Stat. 911 (1935), 11 U.S.C. \& 205(a) (1958).

30. In re Central of Georgia Ry., 42 F. Supp. 940 (S.D. Ga. 1942) apparently contains the only mention of the problem, and there the question was mentioned only in dictum. The Georgia district court expressed doubts that section 77 granted power to require secured creditors in possession to turn over funds to the reorganization trustee, and it stated that even if such a power did exist, it would not be exercised under the particular circumstances of the case. $I d$. at 943 . The amount of money involved was too small to be of significance to the feasibility of the reorganization.

31. 52 Stat. 902 (1938), 11 U.S.C. $\$ 657$ (1958).

32. 52 Stat. 883 (1938), 11 U.S.C. $\$ 506$ (1958).

33. 52 Stat. 902 (1938), 11 U.S.C. \$ 657 (1958).

34. The turnover power employed in ordinary bankruptcy is concerned with a completely different situation. See, e.g., Maggio v. Zeitz, 333 U.S. 56 (1948) ; Cline v. Kaplan, 323 U.S. 97 (1944) ; Harrison v. Chamberlin, 271 U.S. 191 (1926).

35. 52 Stat. 883 (1938), 11 U.S.C. $\$ 501$ (1958). 
acceptance of this argument would leave the courts with less power to maintain uninterrupted service of an interstate railroad during reorganization than to maintain the services of other public utilities and private enterprises. ${ }^{36}$

Had the two reorganization provisions been passed together, the argument based upon juxtaposition of these provisions might be persuasive. But the original section 77 was hurriedly enacted in 1933 to meet the emergency of the depression, ${ }^{37}$ while section $77 \mathrm{~B}$, the predecessor of Chapter $\mathrm{X}$, was enacted the following year, also without an express provision for the turnover power. ${ }^{38}$ Both acts were confusing and poorly written..$^{39}$ The failure of these sections explicitly to include this power is not indicative, since no attempt had been made to assert or deny it. Sale of trustee certificates, the traditional method of raising capital during reorganization, was apparently effective. ${ }^{40}$ Before Congress added the express provision of section 257, however, the Supreme Court had narrowly restricted the jurisdiction of the courts over property not in the possession of the debtor corporation in section 77B reorganization proceedings. In Duparquet Huot \& Moneuse Co. v. Evans ${ }^{41}$ the Court held that when the debtor's property was in the hands of a receiver or trustee in a foreclosure proceeding, as distinguished from an equity receivership, the district court was powerless to secure possession. Tuttle v. Harris ${ }^{42}$ extended this restriction by holding that when a mortgagee was in possession upon default before reorganization, the court had no power over the property. Following the lead of these decisions, some lower courts also held that even where reorganization was commenced before the mortgagee took possession, property later in his hands, or one holding for him, was not subject to the jurisdiction

36. In the case of a railroad, the fact that its continued operation is of vital concern to the public is extremely significant. See, e.g., Joy v. St. Louis, 138 U.S. 1, 47 (1891) ; OrEck, Creditors' Rights ann Remedres 52 (1949); Craven \& Fuller, The 1935 Amendments of the Railroad Barkruptcy Laze, 49 HARv. L. REv. 1254, 1264 (1936).

Although the distinction now may well be fictional, railroads long have been regarded as more affected with the public interest than any other industry. Billyou, Railroad Reorganization Since Enactment of Section 77, 96 U. PA. L. Rev. 793, 821 (1948) ; Note, 1 Staw. L. REv. 676 (1949) ; Whether or not this distinction is unreal, railroads certainly are not less public than other utilities or private industry.

37. Craven \& Fuller, supra note 36 , at 1254,$1258 ; 1$ Collier $\Uparrow 0.06$, at 16 (1961). See note 3 supra.

38. Section 77B, 48 Stat. 911-25 (1934).

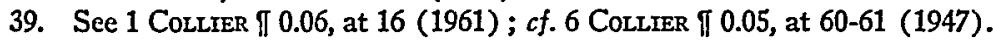

Time was too short to perfect the draft of section 77 as originally passed. 79 CoNG. REc. 13766 (1935) (remarks of Senator Hastings) ; Rodgers \& Groom, Reorganization of Railroad Corporations Under Section 77 of the Bankruptcy Act, 33 CoLum. L. Rev. 571, 572 (1933).

40. In re St. Louis Southwestern Ry., 17 F. Supp. 68 (E.D. Mo. 1936), aff'd sub nom. Bankers Trust Co. v. Henwood, 88 F.2d 163 (8th Cir. 1937); cf., American Brake S. \& F. Co. v. Pere Marquette RR., 205 Fed. 14, 21 (6th Cir. 1913) ; Note, 7 MicH. L. Rev. 239 (1909).

41. 297 U.S. 216 (1936).

42. 297 U.S. 225 (1936). 
of the court. ${ }^{43}$ These decisions provided the impetus for the enactment of the express provision in section 257 of Chapter X.44 Section 77 was not similarly amended at this time, presumably because both courts and commentators recognized that the restrictive interpretations of section 77B were not relevant to railroad reorganization under section 77,45 since railroads rarely had been subject to foreclosure proceedings.

Until Duparquet was decided, sections 77 and 77B had been given parallel constructions in establishing judicial power to restrict the rights of secured creditors. ${ }^{46}$ In Continental Ill. Nat'l. Bank \& Trust Co. v. Chicago, R.I. \& Pac. $R y .{ }^{47}$ one of the earliest cases interpreting either section, the Supreme Court prohibited the sale of pledged collateral by secured creditors of an interstate railroad pending completion of the section 77 reorganization. This collateral consisted of stocks and bonds of the corporation in the possession of the creditor, and the Court feared that the sale of this property would impede, if not destroy, the objectives of reorganization. Although the secured creditors' right to possession 'of the pledged securities was left undisturbed, the contractual rights of such creditors were clearly altered, and the courts' power under section 77 over property no longer in the debtor's possession was established. This and other decisions reveal that section 77 was the more fertile source of judicial authority. It is thus likely that Congress believed that section 77 needed no amending to offset the eroding effects of Tuttle and Duparquet. In fact, a leading commentator at the time inferred from Duparquet's confinement to section $77 \mathrm{~B}$ that courts retained in section 77 reorganizations ${ }^{48}$ a power over property in the possession of secured creditors.

The principles developed as to the powers and jurisdiction of the courts in federal equity receiverships, ${ }^{49}$ incorporated into both the section 77 and Chapter X reorganization acts, ${ }^{50}$ indicate that Congress did not intend the

43. In re Shelburne, Inc., 91 F.2d 190 (3d Cir. 1937) ; Reighard v. Higgins Enterprises, Inc., 90 F.2d 569 (3d Cir. 1937).

44. In re Franklin Garden Apartments, Inc., 124 F.2d 451, $453-54$ (2d Cir. 1941). See also Kaplan, Lyne \& Hurley, The Reorganization of the Walthan Watch Company: $A$ Clinical Study, 64 HARv. L. REv. 1262, 1280 (1951) ; 6 CollIER II 14.01, at 5003 (1947).

45. 6 ColLIER If 14.03, at p. 5009 (1947). Cf. Billyou, Railroad Rearganization Since Enactment of Section 77, 96 U. PA. L. Rev. 793 (1948).

The 1935 amendments also were added too soon after the original enactment to successfully eliminate all its defects and ambiguities. Craven \& Fuller, The 1935 Amendments of the Railroad Bankruptcy Law, 49 HARv. L. REv. 1254, 1258-59 (1936). Moreover, the 1935 amendments did not correct the main faults of section 77. Ibid.

46. Grand Boulevard Inv. Co. v. Strauss, 78 F.2d 180 (8th Cir. 1935); In re PrudenceBonds Corp., 77 F.2d 328 (2d Cir. 1935), cert. denied, 296 U.S. 584 (1935); Central States Life Ins. Co. v. Koplar Co., 80 F.2d 754 (8th Cir. 1935), cert. denied, 298 U.S. 687 (1936).

47. 294 U.S. 648 (1935).

48. Finletter, The Law of Bankruptcy Reorganization 149 n.61 (1939). Cf. Finlettrer, Principles of Corporate Reorganization in Bankruptcy 136 (1937).

49. See, e.g., Billyou, Priority Rights of Security Holders, 67 Harv. L. REv. 553, 582 (1954); Finletter, The Law of Bankruptcy Rzorganization 3 (1939).

50. Section $77($ a), 49 Stat. 911 (1935), 11 U.S.C. $§ 205$ (1958); § 115, 52 Stat. 884 (1938), 11 U.S.C. \& 515 (1958). As long as there is no inconsistency with express pro- 
courts to have less power when dealing with interstate railroads than with private business or other public utilities. The federal equity courts, although reluctant to interfere with the rights of secured creditors of private businesses by issuing trustee certificates, ${ }^{51}$ freely used such certificates to maintain the business operation of railroads and some other public utilities. ${ }^{52}$ Because of the paramount importance of uninterrupted transportation services ${ }^{53}$ and the unique character of railroad property, ${ }^{54}$ the courts were less concerned with the rights of secured creditors in railroad reorganizations.

The jurisdictional provision of section 77, moreover, provides ample statutory authority for the exercise of this power. ${ }^{55}$ The reorganization statutes grant broad jurisdiction stemming from the power to include secured debts in the reorganization plan. Congress believed that in order to rehabilitate the debtor, the court must have power over all the debtor's property, wherever located. ${ }^{56}$ Thus, under section 77, as well as Chapter X, title to property, not possession, is the important factor upon which the court's jurisdiction is predicated. ${ }^{57}$ In a recent case interpreting the jurisdictional provision of Chapter $\mathrm{X},{ }^{58} R F C$ v. Kaplan, 59 the court rejected the argument that because

visions of the statutes, the previous case law applicable to equity receiverships is incorporated into the reorganization statutes:

Good sense and legal tradition alike enjoin that an enactment of Congress dealing with bankruptcy should be read in harmony with the existing system of equity jurisprudence of which it is a part.

SEC v. United States Realty \& Improvement Co., 310 U.S. 434, 457 (1940).

51. While the equity courts generally recognized that they had this power when a private business was involved, they generally used it only to preserve the corporation's properties. In re Prima Co., 88 F.2d 785 (7th Cir. 1937) ; Finletter, The Law of BanKRUPTCY REORGANIZATION 213, 217-18 (1939).

52. Ibid.; 1 ClARK, ReCEIVERS § 469, at 633-64 (2d ed. 1929).

53. Finletter, The Law of BankRuptcy Reorganization 214-15 (1939). As the Supreme Court said in Joy v. St. Louis, 138 U.S. 1, 47 (1891) :

Considerations of the interests of the public are held to be controlling upon a court of equity, when a public means of transportation, such as a railroad, comes into the possession and under the dominion of the court.

See also Whitney, Labor's Interest in Railroad Reorganization, 7 LAW \& Contemp. Prob. 486 (1940).

54. Finietter, The Law of Bankruptcy Reorganization 214-15 (1939). See also 1 CLARK, RECEIVERS $\$ 463$, at 623 (2d ed. 1929).

55. [T] $]$ he court ... shall ... have exclusive jurisdiction of the debtor and its property, wherever located....

Section 77 (a), 49 Stat. 911 (1935), 11 U.S.C. \$ 205(a) (1958).

56. Continental Ill. Nat'l Bank \& Trust Co. v. Chicago, R. I. \& Pac. Ry., 294 U.S. 648 (1935); In re Prudence-Bonds Corp., 77 F.2d 328, 330 (2d Cir. 1935), cert. denied, 296 U.S. 584 (1935) ; Grand Boulevard Inv. Co. v. Strauss, 78 F.2d 180 (8th Cir. 1935); Billyou, Railroad Reorganization Since Enactment of Section 77, 96 U. PA. L. REv. 793, 805 (1948) ; Finletter, The Law of Bankruptcy Reorganization 143, 161-62 (1939).

57. 5 COLLIER \ 77.12, at 502-03 (1954).

58. The court ... shall ... have exclusive jurisdiction of the debtor and its property, wherever located.

Section 11, 52 Stat. 884 (1938), 11 U.S.C. \& 511 (1958). Cf. note 55 supra.

59. 185 F.2d 791 (1st Cir. 1950). 
section 257 does not apply to the particular property in the creditor's possession, no provision authorizes a turnover order displacing the possessory lien of a pledgee. Relying upon the grant of jurisdictional power, it held that the reorganization court had the authority in the course of administering the debtor's assets, pending reorganization, to direct pledgees to turn over property to the reorganization trustee. Since the jurisdictional sections of Chapter $\mathrm{X}$ and section 77 are similar and since both acts were founded upon federal equity receiverships and are thus to be construed mutatis mutandi, this holding seems equally applicable to section 77 reorganization proceedings. ${ }^{60}$

In addition, the objectives of section 77 would be reinforced if courts could compel secured creditors to turn over property to the reorganization trustee. Because the liquidation of a complex railroad corporation is not possible without vast economic waste, ${ }^{61}$ and abandonment is not a realistic alternative, the ICC allowing it only where there will not be any interference with the public convenience and necessity, ${ }^{62}$ the only real alternative for an insolvent

60. After a thorough examination and comparison of the two sections, the court in Grand Boulevard Inv. Co. v. Strauss, 78 F.2d 180, 185 (1935), said:

We think it clear that the scope and purpose of the section [77B] were, broadly speaking, the same as of section 77; and that the powers conferred upon the court to carry out the purpose of the section were equally broad with those conferred in section 77 .

See also Central States Life Ins. Co. v. Koplar Co., 80 F.2d 754 (8th Cir. 1935), cert. denied, 298 U.S. 687 (1936).

Since section 77B was incorporated into Chapter X, Heuston, Corporate Reorganizations Under the Chandler Act, 38 CoLuM. L. REv. 1199, 1200 n.6 (1938), the same parallelism should now exist between the new act and section 77. Cf. 6 CoLLIER If 90.12(2), at 108 (1947). Moreover, RFC v. Kaplan, supra note 59, did not involve a public utility. Surely the jurisdictional powers conferred by section 77 are at least as broad as those conferred by Chapter X over private businesses, even when the latter is coupled with implied power from section 257. In fact, so far-reaching is the long arm of section $\nabla 7$ that Congress saw reason to provide a specific provision to protect conditional vendors and lessors from its grasp. Section $77(\mathrm{j}), 49$ Stat. 922 (1935), 11 U.S.C. $\$ 205(\mathrm{j})$ (1958). See Hearings on H.R. 6249 Before the House Committee on the Judiciary, 74th Cong., 1st Sess. 60 (1935) for the reason behind this special protection.

61. Continental I11. Nat'1 Bank \& Trust Co. v. Chicago, R. I. \& Pac. Ry., 294 U.S. 648, 671 (1935). See also Blum, The Law and Language of Corporate Reorganization, $17 \mathrm{U}$. CHI. L. REv. 565, 566-67 (1950); 1 GERDES, op. cit. supra note 9, § 1, at 3-4.

Unlike corporate reorganizations subject to Chapter $\mathrm{X}$, railroad reorganizations cannot be converted into proceedings in ordinary bankruptcy. Section 4, 36 Stat. 839 (1910), 11 U.S.C. $\$ 22$ (1958).

If the railroad is to be sold, it should be sold as a unit. See Blum, The Law and Language of Corporate Reorganization, 17 U. CHI. L. Rev. 565, 566 (1950); 1 GERDES, op. cit. supra note $9, \S 1$, at 3 .

62. Section 402, 41 Stat. $477-78$ (1920), 49 U.S.C. § 1(18)-(20) (1958). See also Rood, Protecting the User Interest in Railroad Reorganization, 7 LAW \& CoNTEMr. Prob. 495, 497 (1940).

The abandonment attempt would necessitate protracted and expensive proceedings before the ICC. And, in the case of an important interstate railroad, prospects of approval would be dubious. See Harding v. Stichman, 240 F.2d 289, 291 (2d Cir. 1957) ; Crernngron, 
railroad is rehabilitation. ${ }^{63}$ Thus the court under section 77 should at least have the powers available under Chapter $\mathrm{X}$ to effectuate reorganization. The primary objective of section 77 is, in fact, the maintenance of service during the course of reorganization and afterwards. ${ }^{64}$ Unlike the strict adherence to the theory of absolute priority in Chapter $\mathrm{X}$ reorganizations of private businesses, ${ }^{65}$ which assures that senior creditors will be fully paid out of the property and earnings of the business before any payments are made to junior creditors and other investors, the departure in practice from the absolute priority theory in railroad reorganizations ${ }^{B 6}$ indicates a greater concern with rehabilitation than with protection of secured creditors when an interstate railroad is being reorganized. ${ }^{67}$ Since the debtor's funds in the possession of secured creditors frequently constitute the most readily available source of capital during the reorganization, ${ }^{88}$ the power to obtain such funds should be found to exist under section 77.

Assuming the existence of this authority, a court still must decide the circumstances in which the power should be exercised. In making this decision during the interim period, while the reorganization plan is being formulated by the ICC, the court should consider many factors, ${ }^{69}$ since the statute commands

The Regulation of Railroad Abandonments 87-95, $232-35$ (1948) ; Craven, The Judicial and Adninistrative Mechanism of Section 77,7 LaW \& Contemr. РROB. 464 (1940).

The pendency of a railroad reorganization proceeding does not alter the necessity of the debtor's obtaining ICC approval of abandonment. 28 U.S.C. § 959(b) (1958); Thompson v. Texas Mex. R.R., 328 U.S. 134, 144 (1946); Smith v. Hoboken R.W. \& S.C. Co., 328 U.S. 123 (1946).

63. As an insolvent railroad is generally too large to be sold in one piece for more than a token sum and too integrated to be broken up into smaller units, its sale to a private party is generally regarded as unfeasible. Blum, supra note 61 , at 567 .

64. The interest of the public in an adequate transportation service must receive consideration. . . Important property rights must be balanced against the need of sound financing.

Ecker v. Western Pac. R.R., 318 U.S. 448, 482 (1943). See also 2 TARDY's SMITH, RECEIVERs 1578 (2d ed. 1920). Cf. Rood, supra note 62, at 495-97. But see an opinion by Judge Anderson on the New Faven Railroad reorganization, N.Y. Times, March 8, 1962, p. 32, col. 1.

65. Billyou, Priority Rights of Security Holders in Bankruptcy Reorganization: New Directions, 67 HARv. L. REv. 553, 559 (1954).

66. Id. at 568; Billyou, Railroad Reorganization Since Enactment of Section 77, 96 U. PA. L. REv. 793, 812-13 (1948) ; Friendly \& Tondel, The Relative Treatment of Securities in Railroad Reorganization ander Section 77, 7 LAW \& ConTens. PRoB. 421, 423 (1940).

No attempt has been made to insist that the securities issued to a senior class must have a prospective market value of 100 cents on the dollar before a junior class may participate. One hundred per cent paper satisfaction has been deemed sufficient. Ibid.

67. One possible reason for the ICC policy is to provide a broader base from which to obtain capital, by retaining as many parties as possible who have a financial interest. For if any one is likely to invest in an insolvent corporation, it would be earlier investors anxious to save their original outlay.

68. When the success of a business venture is very doubtful, investors are hard to find, and, when available, often demand a prohibitive interest rate in compensation for the risk.

69. Continental Ill. Nat'l Bank \& Trust Co. v. Chicago R. I. \& Pac. Ry., 294 U.S. 648 676-77 (1935) ; Lowden v. Northwestern Nat'1 Bank \& Trust Co., 298 U.S. 160, 165-66 
that reorganization be "fair and equitable" to investors ${ }^{70}$ and economically feasible to rehabilitate the insolvent railroad. ${ }^{71}$ Though a claim that injury will result to secured creditors from a turnover order may not be disregarded, it should be balanced against the necessity of the order to assure the success of whatever plan is eventually confirmed. ${ }^{2}$

In re Third Avenue Transit Co. ${ }^{73}$ the principal case evaluating the factors to be considered by the courts in exercising this power under section 257 of Chapter X, represents an example of the reluctance of the courts to interfere with the rights of secured creditors in order to facilitate the operation of a business during reorganization. The Court of Appeals for the Second Circuit held that the turnover power could be exercised only in the most "extraordinary circumstances" 44 and characterized such power as "far more drastic"75 than the authority to issue prior lien certificates. This court believed that section 257 should not be invoked without clear evidence that it is imperative to obtain funds, which cannot be obtained by bank loans or by the sale of prior lien certificates, and that the creditors whose security is being compulsorily recaptured will not be injured. Indeed, the attempt to raise money via the market mechanism, according to the court, would be a significant indication of the probability of successful reorganization.

But feasibility of reorganization should not be a significant factor in determining whether funds should be turned over to the reorganization trustee. If ultimate success is a strong probability, the court will obviously and properly be more liberal in sanctioning expenditures aimed at maintaining and promoting the operation of the road. ${ }^{78}$ But since a successful reorganization is dependent upon the vicissitudes of a business in an uncertain future, ${ }^{77}$ the court should not be too exacting in its demands of proof on this matter, for accurate appraisal of these contingencies is impossible. ${ }^{78}$ The emphasis in Third Avenute upon the inability of the trustee to obtain funds through prior lien certificates in the commercial market as persuasive evidence of the probability that the debtor cannot successfully be reorganized seems incorrect. The market provides a solution for insolvency when the company is to be liquidated, but reorganization is an alternative the very purpose of which is to avoid liquida-

(1936) ; In re Third Ave. Transit Corp., 198 F.2d 703 (2d Cir. 1952) ; Harding v. Stichman, 240 F.2d 289 (2d Cir. 1957) ; RFC v. Kaplan, 185 F.2d 791, 797 (1st Cir. 1950).

70. Section 77 (e) (1), 49 Stat. 918 (1935), 11 U.S.C. \$ 205(e) (1) (1958).

71. Section 77 (d), 49 Stat. 917 (1935), 11 U.S.C. \& 205(d) (1958). See also § 77(b), 49 Stat. 912 (1935), 11 U.S.C. \& 205(b) (1958).

72. See note 69 supra.

73. 198 F.2d 703 (2d Cir. 1952).

74. Id. at 706 .

75. Ibid.

76. RFC v. Kaplan, 185 F.2d 791 (1st Cir. 1950). Cf. In re Third Ave. Transit Corp., 198 F.2d 703 (2d Cir. 1952).

77. In re Philadelphia \& Reading Coal \& Iron Co., 117 F.2d 976, 978 (3d Cir. 1941); cf. Ecker v. Western Pac. R.R., 318 U.S. 448, 458-59, 508 (1943).

78. Ibid. Cf., Warner, Some Financial and Economic Problems in Railroad Recapitalizations, 7 LaW \& ConteMr. Prob. 438,449 (1940). 
tion. Since section 77 has rejected the market as providing a solution for insolvency, ${ }^{79}$ the market should also be disregarded as a yardstick for measuring the probability of success. Investors are reluctant to lend money to a distressed business, not only because its assets may have little value, but also because its future prospects are uncertain. ${ }^{80}$ But the possibility of a successful reorganization may nevertheless be quite good despite the pessimism of the market, because of the ICC's subsequent changes in both the capital structure and the business operations of the railroad in the ultimate plan of reorganization. Whether reorganization will be successful, moreover, seems to be a question addressed primarily to the ICC for decision after long study and efforts to increase the profits of the insolvent railroad.

Even if the market appraisal is correct and the efforts to reorganize are doomed, the court should, notwithstanding such appraisal, maintain the service and going-concern value of the line. Since abandonment and liquidation of an important interstate railroad do not offer a realistic alternative, ${ }^{81}$ the government will ultimately have to nationalize, or more likely subsidize, the unprofitable road. It would be extremely wasteful to allow the line to deteriorate further during the interim period. In addition, the decrease in the value of the assets during this period would injure the interests of all investors.

The proposed use of the funds in the possession of creditors is, of course, an important determinant. The expenditures must be necessary to maintain the railroad as a going concern and enable it to perform its public functions. ${ }^{82}$ Thus the courts should not tolerate the improvident use of funds merely to increase the equity of junior creditors and stockholders ${ }^{83}$ They should, however, more readily approve a set plan to use the funds for the purchase of tangible

79. Blum, The Law and Language of Corporate Reorganization, 17 U. CHI. L. REv. 565,567 (1950).

80. Ibid.

81. See note 62 supra. Bankers Trust Co. v. Gebhart, 195 F.2d 238 (2d Cir. 1952), appears to have been the only section 77 case in which the abandonment of the railroad operation was seriously considered. Reorganization of the New York, Ont. \& W. R.R. had dragged on for fifteen years and no plan of reorganization had been proposed for the last twelve, because the road was unable to earn even its operating expenses. Therefore, the circuit court ordered the district court to hold a hearing to decide whether to allow the indenture trustee to seek the ICC's consent to abandon operations. Even though the railroad was of little relative importance, extreme measures were needed in order to permit its demise. The federal government initiated a receivership for unpaid taxes, in the course of which the properties were liquidated. See Fooshee \& Billyou, Amendments to Federal Railroad Reorgantization Statute Proposed by the American Bar Association, 16 Bus. LAw. 543 (1961). The necessity for resorting to such an unusual method to terminate service certainly demonstrates how reluctant both the courts and the ICC have been to permit total abandonment.

82. Harding v. Stichman, 240 F.2d 289 (2d Cir. 1957) ; In re Long Island R.R., 95 F. Supp. 919 (E.D.N.Y. 1951); In re St. Louis Southwestern Ry., 17 F. Supp. 68 (E.D. Mo. 1936), aff'd sub. nom. Bankers Trust Co. v. Henwood, 88 F.2d 163 (8th Cir. 1937).

On this point the reorganization trustee bears the burden of proof. In re Prima Co., 88 F.2d 785, 790 (7th Cir. 1937).

83. In re Third Ave. Transit Corp., 198 F.2d 703 (2d Cir. 1952). 
assets ${ }^{84}$ than a vague request for "working capital," as in Third Avemue, which might, under inexpert management, be dissipated. Tangible assets, moreover, may actually increase, or at least prevent a decrease, in the total value of the company's property. ${ }^{85}$ Such expenditures will not substantially prejudice the senior creditors, because their liens will become attached to the newly purchased assets. ${ }^{86}$

A turnover order is not the only method of supplying needed funds during the interim period, and thus a court must consider the availability of other methods before exercising this power. Where the reorganization trustee has sufficient funds from the operation of the business, any interference with secured creditors' rights should not be allowed. ${ }^{87}$ But where such funds are not available, the court must choose between turnover, if there are funds of the debtor in the possession of the secured creditors, and the sale of prior lien certificates in the market. The sale of such certificates creates a new priority scheme by displacing the liens of senior creditors and increases the company's total amount of debt. Courts, reasoning that the rights of secured creditors are more seriously impaired by the transfer of collateral to the reorganization trustee, ${ }^{88}$ have traditionally used the market method wherever possible before issuing a turnover order. But this preference is questionable. Although a turnover order does deprive secured creditors of collateral in their possession and consequently not subject to the risks of the enterprise, the amount of this security is generally a small part of the total debt owed by the company to such creditors. ${ }^{89}$ Since prior lien certificates displace the priority of these creditors in respect to the larger amount owed and ultimate recovery of this amout depends upon the continuance and success of the enterprise, it is doubtful that the sale of prior lien certificates is less injurious to the interests of secured creditors. The sale of these certificates increases the total debt of the company, contrary to the purpose of reorganization, ${ }^{00}$ which is to assure long term solvency by reducing the amount of fixed interest and debt obligations. ${ }^{91}$ Moreover, expenditure of the debtor's funds in the possession of the trustee for the creditors seems more equitable to senior secured creditors and certainly to junior creditors in the long run than the issuance of prior lien certificates. For if the plan is successful, the creditors' security will appreciate in value without their priority position being weakened. ${ }^{22}$

84. Harding v. Stichman, 240 F.2d 289 (2d Cir. 1957) ; In re Long Island R.R., 95 F. Supp. 919 (E.D.N.Y.1951).

85. See, e.g., Harding v. Stichman, supra note 84, at 291.

86. RFC v. Kaplan, 185 F.2d 791 (1st Cir. 1950).

87. Warner, supra note 78, at 446. See also In re Third Ave. Transit Corp., 198 F.2d 703 (2d Cir. 1952).

88. Ibid.

89. Ibid.

90. In re St. Louis Southwestern Ry., 17 F. Supp. 68 (E.D. Mo. 1936), aff'd sub. non. Bankers Trust Co. v. Henwood, 88 F.2d 163 (8th Cir. 1937).

91. See note 6, supra.

92. RFC v. Kaplan, 185 F.2d 791, 797 (1st Cir. 1950). 